\title{
Ukrainian Practice of Virtual Diplomacy
}

\section{Praktyka dyplomacji wirtualnej w Ukrainie}

\section{- Abstrakt •}

Artykuł ukazuje proces transformacji działalności dyplomatycznej państwa następującej pod wpływem informacji internetowej oraz usług komunikacyjnych. Aktualność tego zagadnienia spowodowana jest nowymi możliwościami i wyzwaniami stojącymi przed państwowymi służbami dyplomatycznymi w warunkach istnienia środków komunikacyjnych funkcjonujących ponad granicami państwowymi, takich jak Internet. W szczególności dotyczy ona możliwości ustanowienia kanałów informacyjnych dla określonych odbiorców za granicą oraz informowania społeczności globalnej o własnej działalności. Obecne warunki polityczne oraz ograniczone (w porównaniu z Rosją) możliwości medialne sprawiają, że dla Ukrainy coraz ważniejsze jest wykorzystywanie Internetu by ogłaszać swoje stanowisko w istotnych kwestiach z dziedziny polityki wewnętrznej i zagranicznej.

Słowa kluczowe: dyplomacja, Internet, opinia publiczna, Ukraina

\section{- Abstract •}

The article reveals the processes of transformation of diplomatic activity of the state under the influence of the Internet information and communication services. Relevance of this problem is caused by new opportunities and challenges the state diplomatic service faces under conditions of existence of such cross-border communication media as the Internet. In particular, it includes the possibilities of establishing the channels of target audiences direct informing abroad and operational informing of the world community as for rather topical issues of the state foreign policy. In the present political conditions and limited (compared with Russia) media opportunities it is more important for Ukraine to use the Internet to deliver its position on urgent problems of its domestic and foreign policy.

Keywords: diplomacy, Internet, public opinion, Ukraine 
The diplomacy today in the conditions of the globalized world endures maybe the most revolutionary transformation. Global communication media, on the one hand, made foreign policy activity of the state more transparent, and from the other - provided a technological capability of a direct interaction with foreign audiences. Besides, all the more attention of the society is paid to the state activity on the international scene. The system of taking political decisions, having passed away from the model of complete concentration in the hands of top men and hiding from the others, through "The Public Has to Know Everything" model within which the government of the country had to report somehow on its activity, to the model according to which the social opinion is formed in advance, before certain steps to be taken. The globalization of communications pushed forward a critical requirement of working not only with "one's own", internal public, but also with the international audience. Today the favourable attitude of the foreign community is one of key factors which have direct impact on success of foreign policy events of the state. As it was noticed in 1983 by the ambassador of the USA in Germany of that time, the native of Ukraine Arthur Frank Burns, "The achievement... of true understanding between any two governments depends fundamentally on the kind of relationship that exists between the peoples, rather than on the foreign ministers and ambassadors" (The Human Side of German-American..., 2003).

The British researcher of the contemporary international relations problems Rhiannon Vickers (2004) defined six technological, economic, political, and social changes and challenges the diplomacy faced in the $21^{\text {st }}$ century. First, economic, financial, and information globalisation have produced increasingly porous state boundaries. Second is the "information revolution", the development and rapid expansion of information and communication technologies such as computer processing, digitilisation, the Internet, direct broadcast satellites, and cable systems, resulting in a sharp reduction in the costs and a massive increase in the capabilities of international communications, and an increased ability to share and to access information. Third is the use of these technologies by the media, the proliferation of media outlets and demand for instant news with a 24-hour news cycle, and the internationalisation of the mass media. Fourth is the increasing ability of citizens and non-governmental organisations (NGOs), from transnational pressure groups to transnational terrorist organisations, to access and use these information and communications technologies, and the increased ability to share information with like-minded citizens and groups. Fifth is the development of increasingly critical citizens in democratic states, who are more politically assertive a) as individuals, and b) through NGOs and transnational advocacy or issue networks, resulting in an increased need to gain popular support for policy. Sixth, the development of 
issues (e.g. global warming, international crime, transnational terrorist networks, refugees and migration) and promulgation of norms and values (e.g. democracy and human rights) that diplomacy must deal with are increasingly complex and transnational in nature.

As you can see, these changes and challenges are closely associated with each other. Although, all these transformations were based on the awareness of the necessity of the state to interact directly with the target audiences abroad. The term "public diplomacy", which has been introduced and used confidently in the political and scientific sphere, is understood as a dialogical communication between governments and other actors on the stage of international relations via the mass communication media and non-mediated channels of contact with the foreign countries' mass audience. The aim of public diplomacy is to create or reinforce a positive image of the country and its society, and by influencing the public opinion to shape positive attitudes toward the country, and in consequence to make the achievement of international policy goals easier (Ociepka, 2008).

The concept of public diplomacy comes from the practice of foreign policy activity of the USA. Taking into account that such activity, in particular, during "Cold War" had a completely propagandistic character (using of radio services of Voice of America, Radio Free Europe, and Radio Liberty for propagandistic influence on the Soviet Union and the countries of the Central and Eastern Europe), the politicians and researchers acquired a guarded attitude to the phenomenon of public diplomacy and corresponding practices. Quite an indicative example can be found in a Dictionary of Diplomacy, in the first (Berridge, James, 2001) and the second (Berridge, James, 2003) editions, where the public diplomacy was defined as a late-twentieth-century term for propaganda conducted by diplomats, and only in the third edition (Berridge, Lloyd, 2012) there was an interpretation of this concept as the exploitation by professional diplomats and foreign ministries of the rich opportunities of modern communications technology to engage in a dialogue with foreign publics, albeit with a view to persuading them more effectively to their point of view.

The special role in the processes of transformation of diplomatic practice is played by the Internet. The urgency of the problem of influence of Internet technologies on diplomatic practice has already been a subject of scientific analysis. The phenomenon acquired different names - "virtual diplomacy", "network diplomacy" (net diplomacy), "electronic diplomacy" (e-diplomacy), "cyber diplomacy", "digital diplomacy", "diplomacy 2.0" (and even 3.0), etc.

At its broadest, term "virtual diplomacy" signifies the altered diplomacy associated with the emergence of a networked globe. At its narrowest, term encompasses 
the decision-making, coordination, communication, and practice of international relations as they are conducted with the aid of information and communications technologies (Waller, 2007).

More detailed description of this phenomenon is presented in A Dictionary of Diplomacy mentioned above: "The conduct of diplomacy via electronic information and communications technologies (ICTs), especially the Internet. ICTs have made a great difference to the ways in which states conduct their international communications, both with their own officials abroad and with foreign states, international organizations, and non-governmental organizations. They have also deeply influenced the internal organization of foreign ministries and their diplomatic networks. For example, reliance on the traditional diplomatic bag has steadily diminished as documents have been digitalized, online learning systems are being used more and more for training purposes, and dedicated channels on YouTube and other social media are being exploited" (Berridge, Lloyd, 2012, p. 133).

Therefore it is possible to allocate two dimensions in virtual diplomacy. The first - external, is connected with the use of the Internet for interaction with audiences, target for diplomatic service (and here we can speak about virtual diplomacy as a certain direction of public diplomacy); the second - internal, is connected with the use of the Internet in daily work of diplomatic service (see fig. 1.). Hereafter we will concentrate our attention on the external dimension of virtual diplomacy.

Fig. 1. Ratio of the concepts "public diplomacy" and "virtual diplomacy"

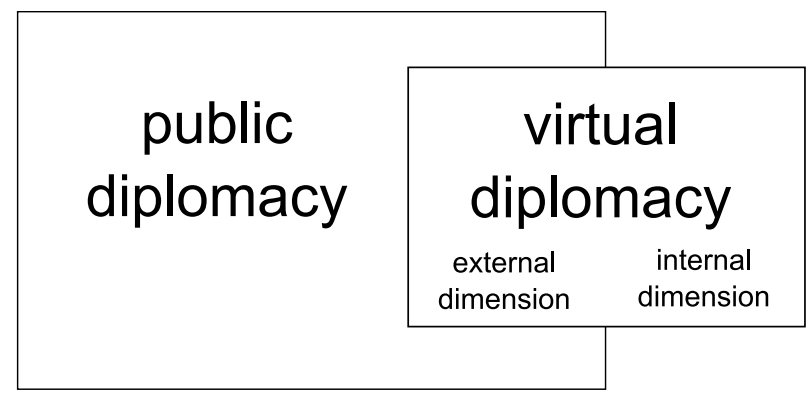

Source: prepared by the author.

One of the directions of using the Internet as cross-border communication media in diplomatic practice was the creation of the so-called "virtual" diplomatic representations - special websites with the functions of informing and establish- 
ment of contacts with the target audience of a certain country or region in which it is inexpedient or impossible to create real diplomatic representations. As an example of such practice we can see the creation of the so-called virtual representations by the US State Department - Virtual Presence Post (VPP). As well as the sites which represent "real" diplomatic representations, virtual representations provide the information oriented to the population of this country (region), and information about the country (region) oriented to citizens of the USA (in such directions as tourism, business, education, etc.).

Utilization of social media by famous politicians, diplomats for the direct delivery to audience of the ideas, position on some issues is one more effective direction of using the Internet in diplomatic practice. Microblog service Twitter became the most popular tool for such communications with audience. Popularity of this service generated a specific concept - Twitter-diplomacy, or "Twiplomacy".

According to the chief executive of the leading world public relations and communications company Burson-Marsteller - Europe, Middle East \& Africa, Jeremy Galbraith, "...Twitter is closing the communication gap between us and our world leaders. On the one hand, it allows heads of state and government to broadcast their daily activities and government news to an ever growing audience. On the other hand it allows citizens direct access to their leaders" (Two thirds of world leaders..., 2013, July 24).

Unprecedented opportunities for feedback represent another aspect of the social media influence on foreign policy activity. Through comments to materials published on the websites of diplomatic missions, foreign policy departments, to posts on pages of these organizations in social networks, etc., and also through own websites, blogs, etc. everyone can introduce the ideas, positions, views. This information can be an invaluable source of information concerning the public opinion (both national and foreign) to the state activity abroad, to representatives of the state (high officials, diplomats), etc.

Speaking about the analysis of the Ukrainian practice of virtual diplomacy, first of all the website of the Ministry of Foreign Affairs of Ukraine (www.mfa.gov. ua) should be noted. Today it is quite a big information portal on which, except the materials connected directly with activity of the ministry, there is a wide range of materials that cover foreign policy activity of the state. In recent years there have been made essential changes to the design of the site the Ministry of Foreign Affairs due to which the site now looks more modern and attractive, and information became more conveniently structured.

In general, in the structure of the web portal of the Ministry of Foreign Affairs of Ukraine there are the following sections: 
- "About Ukraine": the section contains general information about Ukraine, its foreign policy activity, diplomatic representations of foreign states in Ukraine, problems of bilateral cooperation, etc.;

- "About MFA": the section contains information about activity of foreign policy department of Ukraine, its history and the acting head, diplomatic representations abroad, etc.;

- "Consular Affairs": the section contains information on activity of the department of consular service, consular protection of citizens, immigration issues, etc.;

- "Press Center": the section contains information for mass media;

- "Public info": the section is oriented in pursuance of the Ukrainian legislation on the access to public information and contains information about using by the Ministry of Foreign Affairs of Ukraine of budgetary funds, information on tenders, etc. (in the English-language version of the site this section is present, but it is empty);

- "Minister" (actually, this section is the allocated subsection of the section "About the Ministry of Foreign Affairs"): contains information about the head of the MFA, including his biography, interviews, articles, and speeches.

The portal has two language versions - Ukrainian and English.

It should be noted that the Ministry of Foreign Affairs of Ukraine started to use the social media more and more actively, namely (survey was conducted on December 27, 2015):

- Social network "Facebook" (https://www.facebook.com/UkraineMFA/): the page of the Ministry of Foreign Affairs of Ukraine was launched on December 24, 2010, and by now has nearly 23 thousand "likes";

- Microblog service "Twitter" (https://twitter.com/MFA_Ukraine): the page of the Ministry of Foreign Affairs of Ukraine was launched in December, 2010, by now more than 25 thousand tweets have been published, the page has nearly 53 thousand readers and 1400 likes;

- Social network "VKontakte" (http://vk.com/mfa_ukraine): the page of the Ministry of Foreign Affairs of Ukraine by now has more than 1500 records and nearly 30 thousand subscribers;

- Video hosting service "Youtube" (https://www.youtube.com/user/UkraineMFA): the page (channel) of the Ministry of Foreign Affairs of Ukraine was created on December 12, 2012, by now has 349 subscribers and more than 130 thousand reviews;

- Social network "Google +" (https://plus.google.com/10987787123000047 8932): the page of the Ministry of Foreign Affairs of Ukraine was created at 
the beginning of 2014 (judging by the dates of the first publications on the page), by now has only 6 subscribers and nearly 6 thousand reviews (low popularity of the page is probably connected with rather low level of popularity of this social network, in particular, in Ukraine);

- Service for creation of websites and blogs "Wordpress" (https://mfaukraine.wordpress.com/): the blog of the Ministry of Foreign Affairs of Ukraine was created in June, 2015 (judging by the dates of the first publications), there is no information on subscribers;

- Platform for social journalism "Medium" (https://medium.com/@\%20 MFA_Ukraine): the page of the Ministry of Foreign Affairs of Ukraine was created in June, 2015 (judging by the dates of the first publications), by now has more than 1 thousand subscribers;

- Service for creation of the blogs "Blogger" (http://mfaukraine.blogspot. $\mathrm{com} /$ ): the blog of the Ministry of Foreign Affairs of Ukraine was created in June, 2015 (judging by the dates of the first publications). As far as this service belongs to the Google company and is integrated with other Google online services, it can be subscribes through the social network "Google +"; therefore quantity of subscribers to the blog matches the quantity of subscribers to the page of the Ministry of Foreign Affairs in this social network;

- Service of integration of content from different social media "Storify" (https://storify.com/MFA_Ukraine): the page of the Ministry of Foreign Affairs of Ukraine was created in September, 2014 (judging by the dates of the first publications), by now 14 "stories" (separate thematic blocks of information) have been published, the page has only 24 subscribers. It should be noted that updating of the page is quite low;

- Photo hosting service "Instagram" (https://instagram.com/mfa_ukraine/): by now the page of the Ministry of Foreign Affairs of Ukraine contains 94 publications and has more than 300 subscribers;

- Video hosting service "Vine", characterized by opportunity to publish 6-second videos (https://vine.co/u/1208191974160109568): the page of the Ministry of Foreign Affairs of Ukraine was created in May, 2015 (judging by the date of the first publication), by now only 5 videos have been published, the page has more than 200 subscribers. It should be noted that from June, 2015 there have been no updates.

Creation of the websites of national diplomatic representations abroad (embassies, consulates, representations at the international organizations) started in the 1990s. As a rule, they were created by efforts of the diplomatic representations, had 
different design and different models of information filling. The process of creation of new websites of the Ukrainian Embassies on the web portal of the Ministry of Foreign Affairs of Ukraine began in 2007. In 2013, there were essential changes both to the design of these sites, and the information representation model.

Nowadays, all these sites of diplomatic representations share the uniform model of information representation with the following sections:

- "About Ukraine": the section contains the general information about Ukraine, its foreign policy activity, diplomatic representations of foreign states in Ukraine, etc. (this section actually duplicates the appropriate section of the Ministry of Foreign Affairs);

- "Embassy": the section contains information about activity of diplomatic representation, its history and the acting head, contact information (for other types of diplomatic missions the sections are respectively named "Consulate" and "About representation");

- "Ukraine and the country" (present only at the websites of the embassies): the section covers the relations between Ukraine and an adoptive state of embassy, features of life of the Ukrainian diaspora in this country;

- "Ukraine and the organization" (present only at websites of permanent missions at the international institutions): the section is devoted to publicizing of cooperation between Ukraine and this international institution;

- "Consular issues" (present only at websites of embassies and consulates): the section contains information on consular protection of citizens, immigration issues, etc.

- "Press Center": the section contains information for mass media.

- "Ambassador" (either "Consul general", or "Representative"): contains information about the head of the diplomatic mission.

The majority of websites of diplomatic representations of Ukraine have two language versions: Ukrainian and version of the adoptive state language.

It is necessary to notice that information filling of these sites is performed using materials from the portal of the Ministry of Foreign Affairs, which provide a uniform approach in a material feed, and, secondly, ensures fast update and change of these materials. The model of filling of news sections was also implemented on these sites using the materials of the Ministry of Foreign Affairs of Ukraine, which provides news updating at least several times a week. In some cases the information representation model on the specific website can differ from the mentioned one (some subsections can be absent or structured differently).

As for the use of social media, if only several years ago only some diplomatic missions used this communication channel, since 2014 practically for all diplo- 
matic missions' pages in the social network "Facebook" and microblog service "Twitter" were created.

It should be noted that on the portal of the Ministry of Foreign Affairs and websites of the diplomatic representations of Ukraine the banners were published which lead to specially created web portals with image function. In particular, these are the portal "Ukraine Under Attack" (ukraineunderattack.org) and the news portal "Dokaz" (dokaz.org.ua) created due to initiative of the Ukrainian Crisis Media Center and with the assistance of Presidential Administration of Ukraine. Both resources are devoted to publicizing of war in Ukraine, have two operating language versions (Ukrainian and English), and actively use possibilities of social media. At all of these sites there is a banner leading on the site (www.vpo. gov.ua), created in 2014 by the Ministry of regional development, construction and housing and communal services of Ukraine, oriented to providing information for internally displaced citizens (first of all those, who left the zone of armed conflict in the Donbass region of Ukraine).

At the same time, it should be noted that through a portal of the Ministry of Foreign Affairs and the Ukrainian diplomatic missions' sites network only government information resources are promoted, while other websites, which also improve the image of Ukraine in the conditions of the Russian aggression, are ignored. In particular, there is quite popular (judging by the subscribers quantity and likes in social networks) website "Stopfake" (stopfake.org) started on 2 March 2014 as an initiative of teachers, graduates, and students of Mohyla school of journalism and the program for journalists and editors "Digital Future of Journalism". Its task is checking and denial of the distorted information and propaganda about what happens in Ukraine, which is disseminated in the mass media (first those in Russian).

Speaking about the analysis of virtual diplomacy practice at the level of consular establishments, the following should be noted. On the one hand, there were created websites of consular establishments filled with information on consular questions. On the other hand, the websites of consular establishments are oriented mainly to citizens of Ukraine, whereas other target audiences are practically ignored (in particular, versions of the sites in the language of an adoptive country contain much less information on consular issues - there are no appropriate sections or they are empty).

Ukraine, in the context of the conflict with Russia, has one more relevant vector of virtual diplomacy, namely - the use of the websites of the Ukrainian diplomatic representations to ensure support of citizens of Ukraine, who are on the territory of the Russian Federation. The importance of this question is defined by perspectives of termination of diplomatic relations between Ukraine and Russia, 
and if so - termination of functioning of diplomatic missions. Though this step is believed by many to be reasonable, logical, and necessary, nevertheless the head of the diplomatic department of Ukraine Pavlo Klimkin upheld a position of expediency of preserving of the diplomatic relation between two countries, grounding that "in the conditions of termination of the diplomatic relations with the Russian Federation thousands of Ukrainians who are on the territory of Russia will be left without protection" (Укрінформ, 2014, July 22).

A similar position was stated in an interview for the online media "Glavkom" by the newly appointed ambassador of Ukraine to the United Nations Volodymyr Yelchenko: "...then and moreover nowadays to break off the diplomatic relations would mean to leave all our citizens who are there (in Russia), living or working, without protection. Today this part of this work is performed by our embassy in Moscow, and by our four consulate generals left in Rostov, St. Petersburg, Novosibirsk and Yekaterinburg. 99\% of their work is performing consular service to our compatriots. It becomes especially topical after recent introduction in action by Russia of the decision on more accurate control of the Ukrainian citizens staying on the territory of the Russian Federation" (ГАавком, 2015, December 25).

In this situation, irrespectively of a format of further development of diplomatic relations between both countries, Ukrainian diplomatic service should utilize the Internet as the communication channel with the Ukrainian citizens who are on the territory of Russia as much as possible. According to the analysis of the websites of all four Consulate Generals of Ukraine in the Russian Federation (in Yekaterinburg, Novosibirsk, Rostov-na-Donu and St. Petersburg) carried out by the author, all of them contain a wide range of useful information concerning peculiarities of staying of the Ukrainian citizens in Russia. All the sites have the uniform model of information representation that is a result of implementation of the uniform approach to information filling of the sites of diplomatic representations of Ukraine described above. Except for information which is directly connected with consular issues, there are banners which lead to the special websites described above.

There is a drawback regarding the absence of possibility to make an on-line appointment to consulate (similar service is implemented, for example, at websites of the US consulates).

Therefore, we can draw the following conclusions concerning the efficiency of virtual diplomacy practice of Ukraine. Firstly, a fully-fledged network of websites which represent the Ukrainian diplomacy in the "web world" was created in Ukraine: the portal of foreign policy agency of the country, websites of diplomatic representations, and special web portals. Secondly, all types of social media started to be actively used (social networks, microblog services, photo and video host- 
ing), both by the Ministry of Foreign Affairs of Ukraine and diplomatic missions. At the same time it should be noted that some pages of the Ministry of Foreign Affairs in social media actually are not supported that allows to speak about the need of reduction of quantity of the used networks. Besides, some consulates of Ukraine, in particular, in such countries as the USA and Russia have no pages in social media. Thirdly, a positive phenomenon is the creation and promotion through the portal of the Ministry of Foreign Affairs and websites of diplomatic missions of special thematic web portals. Although, a negative practice in this context is ignoring non-governmental initiatives in this sphere. Fourthly, the websites of the Ukrainian consular establishments are directed mainly to the citizens of Ukraine who are abroad, and much less oriented to other target audiences.

The previously mentioned gives the grounds to claim that the practice of virtual diplomacy in Ukraine undergoes a period of formation. Understanding of the need to work actively in the world information space caused by the Russian aggression gave a powerful impulse to use the Internet as a communicative channel by the Ukrainian diplomatic service. At the same time, there is still a large volume of unused opportunities, implementation of which can considerably increase the efficiency of the Ukrainian virtual diplomacy.

\section{References:}

Berridge, G.R., James, A. (2001). A Dictionary of Diplomacy. Basingstoke: Palgrave Macmillan.

Berridge, G.R., James, A. (2003). A Dictionary of Diplomacy (2nd ed.). Basingstoke: Palgrave Macmillan.

Berridge, G.R., Lloyd, L. (2012). The Palgrave Macmillan Dictionary of Diplomacy (3rd ed.). Basingstoke: Palgrave Macmillan.

Burson-Marsteller - Europe, Middle East \& Africa. (2013, July 24). Two Thirds of World Leaders are Engaged in Diplomatic Relations on Twitter, the Latest Burson-Marsteller Twiplomacy Study Finds. Retrieved from: http://burson-marsteller.be/2013/07/twothirds-of-world-leaders-are-engaged-in-diplomatic-relations-on-twitter-the-latestburson-marsteller-twiplomacy-study-finds/.

Ociepka, B. (2008) Public Diplomacy. In: W. Donsbach (red.), The International Encyclopedia of Communication (p. 3956-3960). Malden, MA: Blackwell Publishing.

The Human Side of German-American Relations. American Ambassador Arthur F. Burns Addressed the Übersee Club in Hamburg on Monday March 14, 1983. (2003, May). Retrieved from: http://usa.usembassy.de/etexts/burnsham5688e.htm.

Vickers, R. (2004). The New Public Diplomacy: Britain and Canada Compared. The British Journal of Politics \& International Relations, 6 (2), 182-194. DOI:10.1111/j.1467856X.2004.00133.x. 
Waller, J.M. (ed.). (2007). The Public Diplomacy Reader. Washington DC: The Institute of World Politics Press.

ГАавком (2015, December 25). Посол України в ООН Володимир ЄАьченко: Росія просто скористалася «шансом» на Крим. Retrieved from: http://glavcom.ua/articles/36470.html.

Укрінформ (2014, July 22). Збереження Аипломатичних відносин із Росією є прагматичною необхідністю - КАімкін. Retrieved from: http://www.ukrinform. ua/rubric-iac/1687090.zberegennya_diplomatichnih_vidnosin_iz_rosie_yu_e _pragmatichnoyu_neobidnistyu___klimkin_1956926.html. 